\title{
USE OF SMART LADDER SNAKE MEDIA TO IMPROVE STUDENT LEARNING OUTCOMES OF IV GRADE STUDENTS OF STATE ELEMENTARY SCHOOL I DOROPAYUNG PANCUR REMBANG
}

\author{
Ahmad Hariyadi \\ IKIP PGRI Bojonegoro \\ Email: ahmadhariyadi31@yahoo.co.id
}

\section{Info Artikel}

\section{Sejarah Artikel:}

Diterima 21Agustus 2018

Direvisi 6 November 2018

Disetujui 22 November 2018

\section{Keywords:}

Smart Ladder Snake Learning Media, teacher activity, student activity, learning outcome.

\begin{abstract}
The objectives of this study are to describe the activities of teachers and students during the use of smart ladder snake learning media, as well as to describe the improvement of student learning outcomes after using snake and ladder smart learning media. This type of research was a classroom action research consisting of planning, implementation, observation, and reflection. The subject of this study was the third grade students of State Elementary School in the academic year of 2017/2018. Data collection techniques of this study were observations of teacher, student activities, and tests for student learning outcomes. The results of this study indicate that by using smart snake ladder learning media, it is enable to improve teacher activities, student activities, and students' learning outcomes. Teacher activity cycles are increasing by $20.45 \%$, student activity increases $27.17 \%$, while the student learning outcomes increase 8.91. Conclusion in this study is smart snake ladder learning media is able to improve teacher activity, student activity, and students' learning outcomes in State Elementary School I Doropayung.
\end{abstract}

\begin{abstract}
Abstrak
Tujuan dari penelitian ini adalah untuk mendeskripsikan kegiatan guru dan siswa selama penggunaan media pembelajaran ular tangga pintar, serta untuk menggambarkan peningkatan hasil belajar siswa setelah menggunakan media pembelajaran cerdas ular dan tangga. Jenis penelitian ini adalah penelitian tindakan kelas yang terdiri dari perencanaan, pelaksanaan, observasi, dan refleksi. Subjek penelitian ini adalah siswa kelas tiga Sekolah Dasar Negeri pada tahun akademik 2017/2018. Teknik pengumpulan data dari penelitian ini adalah observasi guru, aktivitas siswa, dan tes untuk hasil belajar siswa. Hasil penelitian ini menunjukkan bahwa dengan menggunakan media pembelajaran ladder ular cerdas, hal ini memungkinkan untuk meningkatkan aktivitas guru, aktivitas siswa, dan hasil belajar siswa. Siklus aktivitas guru meningkat sebesar $20,45 \%$, aktivitas siswa meningkat $27,17 \%$, sedangkan hasil belajar siswa meningkat 8,91 . Kesimpulan dalam penelitian ini adalah media pembelajaran ladder ular cerdas mampu meningkatkan aktivitas guru, aktivitas siswa, dan hasil belajar siswa di SDN I Doropayung.
\end{abstract}

(C) 2018 Universitas Muria Kudus 
Hariyadi, Ahmad

USE OF SMART LADDER SNAKE MEDIA TO IMPROVE STUDENT LEARNING OUTCOMES ...

REFLEKSI EDUKATIKA : Jurnal Ilmiah Kependidikan, Nomor 9, Volume 1, Desember 2018, hlm. 107-111

\section{BACKGROUND}

Learning media is very important for teachers so students do not feel bored when they are learning. The teacher is an educator who greatly determines the development of students, so the quality of the learning process must be improves to the maximum to be able to get maximum results. Social studies learning must be able to actively involve students by presenting learning material that is challenging, impressive, and stimulates the power of creativity so that children are immersed in the fun learning. One of the principles of the application of active learning is learning while playing, by playing with the knowledge, skills, attitudes, and powers of developing children's fantasies. Playing is the activity of children which creates a happy and pleasant atmosphere (Triyuli and Amirudin, 2012: 73).

Learning while playing will create active, innovative, creative, effective, and fun learning $(P A I K E M)$. The application of learning while playing can be by using learning media that can make students motivated to learn. Learning media is a very important component because the media functions as an infrastructure that helps learning activities to run efficiently and effectively (Susanto and Puryanto, 2018: 41).

In fact, learning in the third grade of State Elementary School Doropayung I, the students is still passive because they have not applied the principle of learning while playing, many students consider social studies difficult and boring. Learning only uses less interesting image media so the students are less motivated to learn. Even though learning at the elementary school level should use learning media that are attractive to students so that learning is active, innovative, creative, effective, and fun.

Based on the results of observations on February 20, 2018 that is conducted by researchers in III grade of State Elementary School Doropayung I Pancur in the academic year of 2017/2018, the learning outcomes in social studies subjects, the types of work material are still low. This is proven by the results of the daily test scores of students who are still below the Miminum Mastery Criteria that is set by the school, which is 75 . The average score obtained is 67.83 out of 23 students, only 9 students, $39.13 \%$ who reach Miminum Mastery Criteria score, the remaining 14 students, $60.87 \%$ have not been able to reach the Miminum Mastery Criteria score.
The reason of the low student learning outcomes in social studies subject, on the types of work material is learning is still teacher-centered, so students tend to be passive. Teachers only use image media that are less attractive during learning so students are less motivated to learn.

\section{RESEARCH METHODOLOGY}

This type of research was Classroom Action Research, because the problems that researcherss examine were problems that originate from real and actual problems that occur in classroom learning. The researchers used the Spiral model (in Arikunto, 2011: 16) as a research model. The location of this study was located on Brawijaya Street, precisely at State Elementary School I Doropayung. This research was conducted from February to April 2018 in the second semester, in the academic year of 2017/2018. The subjects of this study were the third grade students of State Elementaru School I Doropaung, tolalled 23 students, consisting of 13 male students and 10 female students. Researchers used data collection techniques that were appropriate to the problem, they are observation and testing. In this study, the research data was taken using two research instruments, they are the observation sheet and the test sheet.

According to Aries and Haryono (2012: 95) to calculate the results of observation of teacher activities, the following formula can be used

The percentage of teacher activity $=\frac{\text { The achieved score }}{\text { Maximum score }} \times 100 \%$

To calculate the results of observation of student activities, the following formula can be used

The percentage of sudent activity $=\frac{\text { The achieved score }}{\text { Maximum score }} \times 100 \%$

According to Sudjana (2011: 109) the average can be calculated using the formula:

$$
\mathrm{X}=\frac{\sum \mathrm{X}}{\sum \mathrm{N}}
$$

Students are said to be complete if they are able to achieve the Miminum Mastery Criteria score of 75 and classical completeness of 75\%. According to Aries and Haryono (2012: 95) to calculate the percentage of mastery 
Hariyadi, Ahmad

USE OF SMART LADDER SNAKE MEDIA TO IMPROVE STUDENT LEARNING OUTCOMES ...

REFLEKSI EDUKATIKA : Jurnal Ilmiah Kependidikan, Nomor 9, Volume 1, Desember 2018, hlm. 107-111

learning, it can be calculated by the following formula:

The percentage of student completeness $=\frac{\text { ¿The achieved score }}{\text { ZMaximum score }} \times 100 \%$

\section{RESULTS DAN DISCUSSION}

\section{Cycle I}

Observation Results of Teacher Activities

The total score obtained from 11 observation aspects for teachers is 32 , with a percentage of $72.73 \%$. So that it can be said that the success of teacher activities in carrying out learning in the first cycle is good, but it will still be improved in the second cycle.

\section{Observation Results of Student Activities}

The total score of 23 students is 676 with the percentage of classics as much as $66.80 \%$, so that in the first cycle the activities of students during learning are included in the sufficient category. Seeing this fact, it will be carried out improvements in the second cycle to get better grades of student activity.

\section{Students Learning Outcomes}

Based on data from 23 students, it is obtained an average score of 76.74 with the number of students completed as many as 17 students or equal to $73.91 \%$ and those who did not complete as many as 6 students or equal to $26.09 \%$. The data shows an improvement in learning outcomes from pre-cycle to cycle 1, although classically students have not yet finished learning. Students who reach the Miminum Mastery Criteria score $(\geq 75)$ are $73.19 \%$ smaller than the desired completion percentage of $75 \%$. Student learning outcomes obtained in the first cycle will be improved in cycle II.

\section{Cycle II}

\section{Observation Results of Teacher Activities}

Based on the total score obtained from 11 aspects of observation for teachers, as many as 41 , with a percentage of $93.18 \%$. So that it can be said that the success of teacher activities in implementing social studies learning in cycle II has been very good. This shows an increase in the success of teacher activities in the learning process from cycle I to cycle II.

\section{Observation Results of Student Activities}

The total score of 23 students ia 951 with a classical percentage of $93.97 \%$, so that in the second cycle the activities of students during Social Studies learning are in very good categories. This shows an improvement in student learning activities from the cycle to cycle II, so it can be concluded that the second cycle is in accordance with the learning improvement plan.

\section{Students Learning Outcomes}

Based on 23 students, it is obtained an average score of 85.65 with the number of students completed as many as 21 students or equal to $91.30 \%$ and those who did not complete as many as 2 students or equal to $8.70 \%$. Classically students have finished learning, because students who reach the Miminum Mastery Criteria score $(\geq 75)$ are $91.30 \%$ greater than the desired percentage of completeness which is $75 \%$. These results indicate an increase in learning outcomes from cycle I to cycle II.

\section{DISCUSSION \\ Teacher Activity}

In cycle $\mathrm{I}$, it is obtained the percentage of teacher activity of $72.73 \%$ and teacher activities during the learning process using the snake ladder smart media included in category $G$ (Good). In cycle II, it is found the percentage of teacher activity amounted to $93.18 \%$, from table 4.9 it can be seen that the activity of teachers during the learning process using the media snake ladder smart is included in category $\mathrm{E}$ (Excellent/Very Good). The observation of teacher activities during the learning process using the snake ladder smart media in cycle II is better than the first cycle and has improved, it can be concluded that the activity of the teacher during learning using the snake ladder smart media has improved.

\section{Student Activity}

In cycle $I$, it is found the percentage of student activities amounting to $66.80 \%$ and student activities during the learning process using the snake ladder smart media included in category S (Sufficient). In cycle II, it is found the percentage of student activity at $93.97 \%$, from table 4.9 it can be seen that student activity during the learning process using the snake ladder smart media is included in category $G$ (Good), thus observing student activities during the learning process using snake media smart 
Hariyadi, Ahmad

USE OF SMART LADDER SNAKE MEDIA TO IMPROVE STUDENT LEARNING OUTCOMES ...

REFLEKSI EDUKATIKA : Jurnal Ilmiah Kependidikan, Nomor 9, Volume 1, Desember 2018, hlm. 107-111

ladder cycle II is better than the first cycle and has improves, it can be concluded that the activity of students during the learning process using the media snake ladder smart has improved.

\section{Learning Outcome}

Student learning outcomes show an improvement from the pre-cycle number of $39.13 \%$ to the first cycle with the amount of $73.19 \%$ and to the second cycle with the amount of $91.30 \%$. This shows that the use of smart snake ladder learning media can facilitate mastery of the material delivered by the teacher and can work the group well. Learning outcomes of the first cycle is 1765 with an average of 76.74 and students who completed as many as 17 students with classical completeness of $73.91 \%$, classical criteria "Sufficient". While the learning outcome of cycle II is 1970 and an average of 85.65 so that it can be calculated the percentage of classical completeness as many as 21 students at $91.30 \%$, classical criteria "Proficient", so that it can be declared proficient in cycle II.

\section{CONCLUSION}

Based on the results of the analysis it can be concluded as follows: 1) Teacher activity during the learning process has improved from cycle I to cycle II. The percentage in cycle I is $72.73 \%$ with a good category and improves to $93.18 \%$ in the second cycle with a very good category. This shows that teacher activity from cycle I to cycle II has improved by $20.45 \%$. 2) Student activities during the learning process using the smart snake ladder media have improved. In the first cycle, the results of observations of student activities got a percentage of $66.80 \%$ with sufficient categories and it improves to $93.97 \%$ in the second cycle with a very good category. This shows that teacher activity from cycle I to cycle II has increased by $27.17 \%$. 3) The improvement of student learning outcomes during the learning process using the snake ladder smart media can be seen in the results of student learning tests from pre-cycle, cycle I, and cycle II. In pre-cycle obtained an average value of 67.83 then increased to 76.74 in the first cycle and increased again to 85.65 in the second cycle. So that on average in cycle I to cycle II there is an improvement of 8.91. While for completeness in pre-cycle obtained a percentage of $39.13 \%$ then it improves to $73.91 \%$ in the first cycle and improves again to $91.30 \%$ in the second cycle, so that in the second cycle the students had fulfill mastery learning.

\section{REFERENCES}

Aries, Erna Febru dan Haryono, Ari Dwi. 2012. Penelitian Tindakan Kelas. Yogyakarta: Aditya Media Publishing.

Arifaturufaida. 2015. Penerapan Metode Diskusi Kelompok dengan Menggunakan Media Permainan Ular Tangga untuk Meningkatkan Hasil Belajar pada Mata Pelajaran IPS (Penelitian Tindakan Kelas pada Siswa Kelas III di Madrasah Ibtida'iyah Mamba'ul Huda Al-Ishlamiyah NgabarPonorogo Semester Genap Tahun Pelajaran 2014/ 2015). Skripsi. Ponorogo: Sekolah Tinggi Agama Islam Negeri (STAIN).

Arikunto. 2011. Penelitian Tindakan Kelas. Jakarta: PT Bumi Aksara.

Arsyad, Azhar. 2013. Media Pembelajaran. Jakarta: PT Rajagrafindo Persada.

Aqib, Zainal. 2016. Model-model, Media dan Strategi Pembelajaran Kontekstual (Inovatif). Bandung: Yrama Widya.

Budiningsih, Astri. 2012. Belajar dan Pembelajaran. Jakarta: PT Rineka Cipta.

Hamdani. 2011. Strategi Belajar Mengajar. Bandung: Pustaka Setia.

Hermawati, Giniung Luxcyana. 2016. Keefektifan Media Ular Tangga terhadap Hasil Belajar IPS Materi Koperasi Siswa Kelas IV Di SDN Gugus Diponegoro Semarang. Skripsi. Semarang: Fakultas Ilmu Pendidikan Universitas Negeri Semarang.

Jamil, sya'ban. 2016. Permainan Cerdas dan Kreatif. Jakarta: Penebar Swadaya Grup.

Kanzunnudin, Moh., dan Oktavianti, Ika. 2015. Peningkatan Hasil Belajar IPS Melalui Model Contextual Teaching and Learning Pada Siswa Kelas IV SD 2 Bacin Kudus Tahun 2013/2014. REFLEKSI EDUKATIKA 5 (1) 
Hariyadi, Ahmad

USE OF SMART LADDER SNAKE MEDIA TO IMPROVE STUDENT LEARNING OUTCOMES ..

REFLEKSI EDUKATIKA : Jurnal Ilmiah Kependidikan, Nomor 9, Volume 1, Desember 2018, hlm. 107-111

Murti, Atika Anggareta Widya. 2017. Pengembangan Media Berbentuk Game Interaktif Ular Tangga untuk Meningkatkan Motivasi Belajar Siswa dalam Pelajaran Akuntansi Kelas X SMKN 1 Godean Tahun Ajaran 2016/ 2017. Skripsi Tidak Diterbitkan. Yogyakarta: Fakultas Ilmu Pendidikan Universitas Sanata Dharma Yogyakarta.

Pratiwi, IA., Ardianti, SD., dan Kanzunnudin, Moh. 2018. Peningkatan Kemampuan Kerjasama Melalui Model Project Based Learning (Pjbl) Berbantuan Metode Edutainment Pada Mata Pelajaran Ilmu Pengetahuan Sosial. Refleksi Edukatika: Jurnal Ilmiah Kependidikan 8 (2).

Sakdiyah, Siti Halimatus. 2011. Konsep Dasar IPS di SD. Tuban: Universitas PGRI Ronggolawe.

Sanjaya, Wina. 2011. Penelitian Tindakan Kelas. Jakarta: Kencana Prenada Media Group.
Sudjana, Nana. 2011. Penilaian Hasil Proses Belajar Mengajar. Bandung: PT Remaja Rosdakarya.

Susanto, Ahmad. 2016. Teori Belajar Pembelajaran di Sekolah Dasar. Jakarta: Prenademia Group.

Susanto, Didi dan Puryanto, Sidik. 2018. Pendidikan IPS. Lamongan: CV. Pustaka Ilalang Group.

Sugiyono. 2015. Metode Penelitian Pendidikan. Bandung: Alfabeta.

Triyuli, Kurnia dan Amirudin. 2012. Materi dan Pembelajaran IPS SD. Tuban: Universitas PGRI Ronggolawe.

Wati, Ambar. 2017. Meningkatkan Kemampuan Berbicara dengan Menggunakan Media Permainan Ular Tangga, (Online), Vol.1 No.1. 